\title{
ANALISIS ORIENTASI PELAYANAN MELALUI SEMANGAT TIM DALAM UPAYA MENINGKATKAN KEPUASAN KONSUMEN MENGGUNAKAN MODEL SERV*OR (STUDI KASUS PADA PERAWAT RSUD ABDUL WAHAB SJAHRANIE SAMARINDA)
}

\author{
Deasy Kartika Rahayu ${ }^{1}$ dan Nadia Tri Handayani ${ }^{2}$ \\ ${ }^{1}$ Program Studi Teknik Industri Universitas Mulawarman Samarinda \\ ${ }^{2}$ Dokter Gigi Puskesmas Pemerintah Kota Samarinda \\ e-mail: deasykartika@gmail.com
}

\begin{abstract}
ABSTRAK
Orientasi pelayanan adalah bagian dari iklim organisasi. Orientasi pelayanan mendefinisikan sebagai serangkaian kegiatan organisasi yang dirancang untuk menciptakan dan memberikan pelayanan yang sangat baik. Orientasi pelayanan adalah pilihan strategis untuk menciptakan layanan yang sangat baik. Layanan organisasi didorong akan memberikan keuntungan psikologis kepada karyawan seperti semangat tim (esprit de corps) dan komitmen organisasi. Semangat tim penting karena efektivitas dan kinerja organisasi yang bergantung pada kerja tim. Produktivitas dan kinerja organisasi dipengaruhi oleh komitmen. Penelitian ini bertujuan untuk mengidentifikasi hubungan antara orientasi pelayanan dan semangat tim (esprit de corps) dan komitmen organisasi dan juga antara semangat tim (esprit de corps) dan komitmen organisasi. Penelitian ini merupakan penelitian kuantitatif dengan menggunakan desain cross sectional. Subyek penelitian ini adalah perawat yang bekerja di RSUD Abdul Wahab Sjahranie Samarinda. Variabel bebas adalah orientasi pelayanan yang diukur dengan menggunakan Serv * OR. Variabel dependen adalah semangat tim (esprit de corps) dan komitmen organisasi. Data dianalisis dengan menggunakan korelasi dan analisis regresi. Studi ini menunjukkan bahwa ada hubungan positif yang signifikan antara orientasi pelayanan dan semangat tim (esprit de corps) $(r=+0396$, sig $<0,05)$, antara orientasi pelayanan dan komitmen organisasi $(r=0.432$, sig $<0,05)$, dan antara semangat tim (esprit de corps) dan komitmen organisasi ( $r=0.538$, sig $<0,05)$. Pemberdayaan karyawan memberikan kontribusi terkecil untuk tim semangat dan memberi kontribusi tidak untuk komitmen organisasi antara perawat di RSUD A.W.Sjahranie Samarinda.
\end{abstract}

Kata kunci: Layanan Orientasi, Serv * OR, Esprit De Corps, Komitmen Organisasi.

\begin{abstract}
Service orientation is a part of organization's climate. Service orientation defines as the set of organizational activities designed to create and deliver an excellent service. Service orientation is a strategic choice to create an excellent service. Service driven organization will give psychological benefits to employee such as team spirit (esprit de corps) and organizational commitment. Team spirit is important because the effectiveness and organization's performance are depended on team work. Productivity and organization's performance are influenced by commitment. The study was intended to identify the relationship between service orientation and team spirit (esprit de corps) and organizational commitment and also between team spirit (esprit de corps) and organizational commitment. This study was quantitative research using cross sectional design. The subjects of this study were nurses who work at RSUD Abdul Wahab Sjahranie Samarinda. The independent variable was service orientation which measured using SERV*OR. The dependent variables were team spirit (esprit de corps) and organizational commitment. The data were analysed using correlation and regression analysis. This study showed that there were significant positive relationship between service orientation and team spirit (esprit de corps) $(r=+0,396$, sig $<0,05)$, between service orientation and organizational commitment $(r=$ $+0,432$, sig $<0,05$ ), and between team spirit (esprit de corps) and organizational commitment ( $r=$ $+0,538$, sig <0,05). Employee empowerment gave the smallest contribution to team spirit and gave none contribution to organizational commitment among nurses at RSUD A.W.Sjahranie Samarinda.
\end{abstract}

Keywords: Service Orientation, SERV*OR, Esprit De Corps, Organizational Commitment.

\section{PENDAHULUAN}

Seiring dengan majunya ilmu dan teknologi kedokteran serta makin baiknya tingkat pendidikan dan keadaan sosial ekonomi masyarakat, pelayanan kesehatan yang bermutu harus mulai diperhatikan. Mutu pelayanan adalah tingkat kesempurnaan standar yang memuaskan konsumen dan petugas pemberi pelayanan. 
Organisasi diartikan sebagai sekelompok orang yang saling berinteraksi untuk mencapai tujuan. Rumah sakit merupakan salah satu tempat penyelenggaraan pelayanan kesehatan yang karyawannya berinteraksi langsung dengan pelanggan, sehingga rumah sakit dapat disebut sebagai organisasi.

Variabel organisasi yang selalu diperhatikan oleh akademisi maupun profesional bisnis adalah orientasi organisasi. Orientasi organisasi yakni orientasi pelayanan (service orientation) dapat mempengaruhi kinerja organisasi. Orientasi pelayanan diartikan sebagai aktivitas organisasi yang didesain untuk menciptakan dan memberikan pelayanan prima. Orientasi pelayanan merupakan pilihan strategik untuk menyelenggarakan pelayanan prima (service excellence). Pelayanan prima tidak dapat tercapai secara alami. Pelayanan prima haruslah direncanakan dan terkoordinasi.

Orientasi pelayanan suatu organisasi pelayanan diukur menggunakan Service Orientation (SERV*OR). SERV*OR mengukur 4 dimensi, yaitu service leadership practices, service encounter practices, human resource management practices, dan service system practices. Keempat dimensi ini dijabarkan dalam 10 faktor dan tiap faktor diukur dengan menggunakan item spesifik. SERV*OR dimaksudkan untuk mengukur sejauh mana organisasi dipersepsikan dan diyakini oleh karyawannya sebagai organisasi yang menerapkan kebijakan, praktek, dan prosedur spesifik yang mencerminkan pelayanan prima atau bermutu tinggi (service excellence). SERV*OR merupakan skala yang universal dan dapat digunakan pada berbagai jenis pelayanan, yaitu retail building suppliers (Lytle et al., 1998), bank (Lytle et al., 1998; Lytle dan Timmerman, 2006), pelayanan kesehatan (Yoon et al., 2007), dan firma (Urban, 2009).

Organisasi yang berorientasi pelayanan akan memberikan manfaat psikologis bagi karyawannya berupa semangat tim (esprit de corps) dan komitmen terhadap organisasi. Semangat tim diartikan sebagai perasaan sebagai satu tim untuk bersama-sama mencapai tujuan organisasi yakni melayani pelanggan. Komitmen merupakan keterikatan psikologis yang dirasakan karyawan kepada organisasi yang menciptakan kebanggaan dalam diri karyawan karena menjadi bagian dari organisasi.

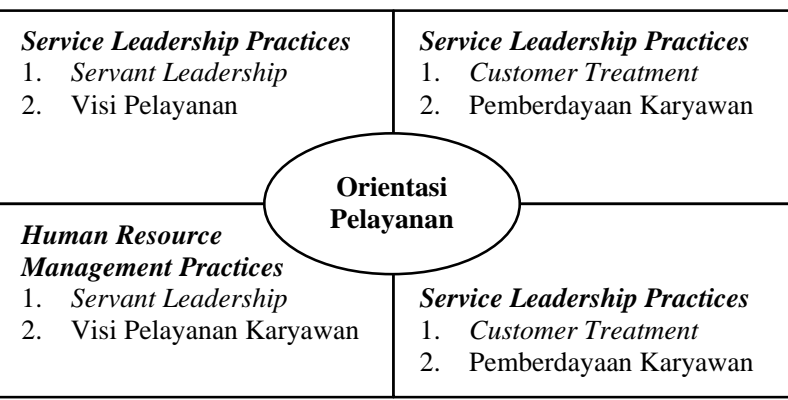

Gambar 1. Dimensi SERV*OR

Semangat tim mencakup adanya kebersamaan, persahabatan, dan kepedulian di antara anggota organisasi, bangga dan setia menjadi bagian dari organisasi, serta mengutamakan kepentingan organisasi daripada individu. Semangat tim dalam kerja sama tim memiliki peran penting karena semangat tim menentukan efektivitas dan kinerja organisasi.

Konsekuensi dari adanya semangat tim dalam organisasi adalah terciptanya komitmen terhadap organisasi, yang terbentuk dari identifikasi individu terhadap organisasi dan keinginan untuk tetap bekerja di organisasi tersebut. Ketika karyawan meyakini dan menerima nilai organisasi, organisasi menjadi lebih menyenangkan sebagai tempat bekerja dibandingkan tempat lain dan kecenderungan untuk meninggalkan organisasi akan menurun.

Komitmen mempengaruhi produktivitas dan kinerja organisasi karyawan terhadap organisasi. Komitmen secara umum dapat ditandai adanya tiga komponen utama, yaitu suatu kepercayaan yang kuat dan penerimaan terhadap tujuan dan nilai organisasi, kemauan untuk melaksanakan kegiatan untuk organisasi, dan keinginan untuk tetap menjadi anggota organisasi.

Rumah Sakit Umum Daerah (RSUD) Abdul Wahab Sjahranie adalah rumah sakit kelas B-Pendidikan milik Pemerintah Provinsi Kalimantan Timur yang bertempat di kota Samarinda. RSUD A.W. Sjahranie memiliki visi untuk memberikan pelayanan kesehatan terbaik di Kalimantan Timur. RSUD A.W.Sjahranie selalu berusaha untuk memenuhi tuntutan dan kebutuhan pelanggan. RSUD 
A.W.Sjahranie terdiri dari pelayanan rawat jalan, pelayanan rawat inap, gawat darurat, dan pelayanan penunjang. RSUD A.W. Sjahranie memiliki 999 karyawan yang terdiri dari tenaga medis dan nonmedis. Sebagian besar karyawan adalah tenaga medis perawat dengan jumlah 394 orang di ruang rawat inap.

Keberadaan perawat dalam rumah sakit adalah sangat penting. Perawat, dokter, dan pasien merupakan kesatuan yang saling membutuhkan dan tidak dapat dipisahkan. Tenaga perawat dapat dianggap sebagai ujung tombak pelayanan rumah sakit karena perawat berperan sebagai penjalin kontak terlama dengan pasien melalui pelayanan keperawatan yang berlangsung berkesinambungan selama 24 jam sehari. Pelayanan yang diberikan oleh perawat mempengaruhi penilaian baik buruknya pelayanan rumah sakit. Perawat adalah mereka yang memiliki kemampuan dan kewenangan melakukan tindakan keperawatan berdasarkan ilmu yang dimiliki diperoleh melalui pendidikan keperawatan.

Dengan SERV*OR dapat dilihat bagaimana orientasi pelayanan menurut perawat serta mengidentifikasi hubungan orientasi pelayanan (service orientation) dengan semangat tim (esprit de corps) dan komitmen terhadap organisasi pada perawat di RSUD Abdul Wahab Sjahranie Samarinda.

\section{METODOLOGI PENELITIAN}

Model SERV*OR merupakan penelitian kuantitatif dengan rancangan cross sectional. Jumlah sampel yang digunakan adalah 195 perawat. Pengambilan sampel dilakukan dengan menggunakan cara proportional random sampling.

Instrumen yang digunakan pada penelitian ini berupa kuesioner, yaitu lembar data demografi (karakteristik responden berupa umur, masa kerja, unit kerja, dan jenis tenaga), kuesioner untuk mengukur orientasi pelayanan (service orientation) sebanyak 35 item, semangat tim (esprit de corps) sebanyak 7 item, dan komitmen organisasi sebanyak 12 item. Kuesioner menggunakan skala Likert dengan 5 tingkatan dari sangat tidak setuju sampai sangat setuju.

Gambar 3 memberikan kerangka acuan dalam permasalahan yang dapat diselesaikan dengan menggunakan model SERV*OR. Organisasi yang berorientasi pelayanan akan memberikan manfaat psikologis bagi karyawannya berupa semangat tim (esprit de corps) dan komitmen terhadap organisasi (Jaworski dan Kohli, 1993). Lytle dan Timmerman (2006) menyatakan bahwa orientasi pelayanan berhubungan dengan outcome karyawan berupa semangat tim dan komitmen. Semangat tim dalam kerja sama tim berperan penting karena semangat tim menentukan efektivitas dan kinerja organisasi

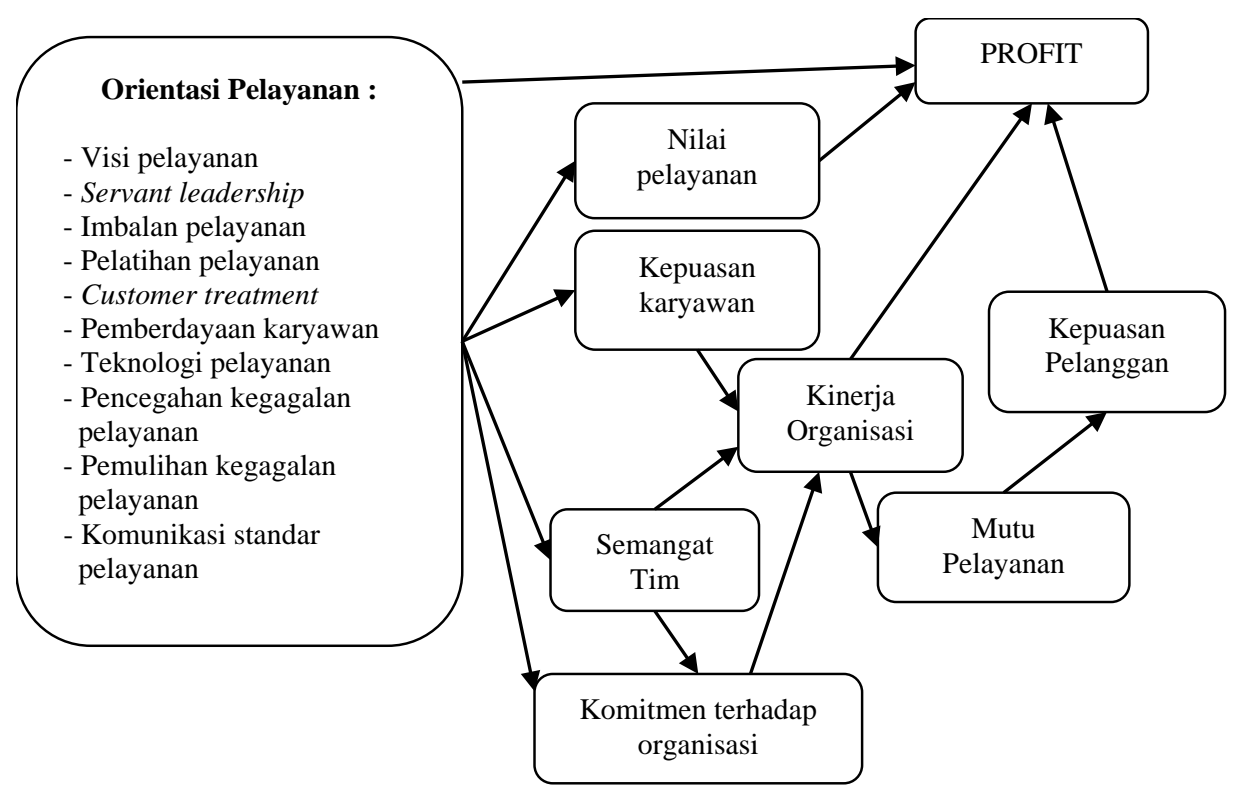

Gambar 2. Kerangka Teori 
(Purba dan Seniati, 2004). Sementara itu, produktivitas dan kinerja organisasi juga dipengaruhi oleh adanya komitmen karyawan terhadap organisasi (Balfour dan Wechsler, 1996 cit Warsi et al., 2009).

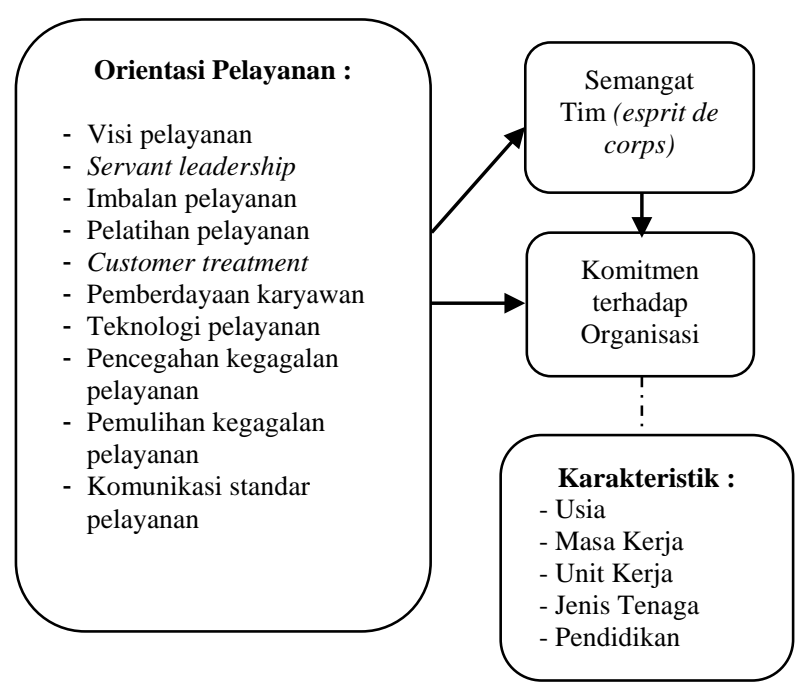

Gambar 3. Kerangka Permasalahan

Semangat tim mencakup adanya kebersamaan, persahabatan, dan kepedulian di antara anggota organisasi, bangga dan setia menjadi bagian dari organisasi, serta mengutamakan kepentingan organisasi daripada individu. Konsekuensi dari adanya esprit de corps dalam organisasi adalah terciptanya komitmen terhadap organisasi, yang terbentuk dari identifikasi individu terhadap organisasi dan keinginan untuk tetap bekerja di organisasi tersebut. Dengan semakin tingginya esprit de corps dalam organisasi, maka akan semakin tinggi pula komitmen terhadap organisasi (Boyt et al., 2005).

Semangat tim ini menjadikan karyawan berorientasi tim. Karyawan yang berorientasi tim biasanya memiliki masa kerja yang lama dalam organisasi tersebut karena merasa senang dengan suasana lingkungan kerja yang kekeluargaan (Teng dan Barrows, 2009).

Komitmen terhadap organisasi merupakan hal yang penting karena karyawan yang terikat secara emosional biasanya bekerja dengan lebih baik serta berorientasi ke arah pencapaian tujuan organisasi yang bersangkutan (Mobley et al., 1979). Komitmen secara umum dapat ditandai adanya tiga komponen utama, yaitu suatu kepercayaan yang kuat dan penerimaan terhadap tujuan dan nilai organisasi (value commitment), kemauan untuk melaksanakan kegiatan untuk organisasi (effort commitment), dan keinginan untuk tetap menjadi anggota organisasi (retention commitment). Dengan kata lain, karyawan yang berkomitmen tinggi akan tetap berada dalam organisasi dan berusaha keras untuk mencapai tujuan organisasi (Porter et al., 1974).

Pelayanan profesional terhadap masyarakat memerlukan integritas, komitmen moral, dan tanggung jawab etik. Pelayanan keperawatan profesional tidak mungkin terwujud tanpa adanya komitmen perawat dalam memberikan pelayanan yang bermutu, baik secara mandiri ataupun melalui jalan kolaborasi dengan tenaga kesehatan lain (Beauchamp dan Walters,1989 cit Joe, 2009).

Variabel independen adalah orientasi pelayanan yang diukur menggunakan SERV*OR. Variabel dependen adalah semangat tim (esprit de corps) dan komitmen organisasi. Analisis data menggunakan analisis deskriptif, korelasi dan regresi. Analisis deskriptif digunakan untuk pemaparan gambaran secara umum karakteristik subyek penelitian. Analisis korelasi bertujuan untuk mengetahui hubungan antara orientasi pelayanan dengan semangat tim dan komitmen terhadap organisasi serta mengetahui hubungan antara semangat tim dengan komitmen terhadap organisasi. Analisis regresi bertujuan untuk mengetahui komponen mana dari orientasi pelayanan yang memberikan kontribusi terbesar terhadap semangat tim dan komitmen organisasi,

\section{PEMBAHASAN DAN ANALISIS}

Responden terdiri dari $41,4 \%$ berusia 21 30 tahun, 39,2\% berusia 31-39 tahun, dan $19,4 \%$ berusia $\geq 40$ tahun. Kelompok responden menurut masa kerjanya yaitu responden yang telah bekerja selama 1-5 tahun sebanyak 30,9\%, $>15$ tahun sebanyak 28,8\%, 6-10 tahun sebanyak 20,4\%, 11-15 tahun sebanyak 14,1\%, dan $<1$ tahun sebanyak 5,8\%. Unit kerja yang dilibatkan dalam penelitian ini berjumlah 17 unit. Sebagian responden sejumlah 89\% merupakan PNS dan 11\% adalah tenaga honorer. Pendidikan terakhir responden yaitu 89\% Diploma 3 (D3). 6,8\% Sarjana Strata 1 
(S1), 2,6\% Diploma 4 (D4), 0,5\% SPK, 0,5\% Diploma 1 (D1), dan 0,5\% S2.

Berdasarkan kerangka permasalahan, orientasi pelayanan, semangat tim, dan komitmen organisasi memiliki hubungan yang positif yang kuat dengan kinerja bisnis yang pada akhirnya meningkatkan profit. Hipotesis awal yang dibangun adalah: (1). Orientasi pelayanan berhubungan positif dengan semangat tim. (2). Orientasi pelayanan berhubungan positif dengan komitmen organisasi. (3). Semangat tim berhubungan positif dengan komitmen terhadap organisasi. (4). Pemberdayaan karyawan memberikan kontribusi terbesar terhadap semangat tim dan komitmen organisasi pada perawat di RSUD A.W.Sjahranie Samarinda.

Hasil yang diperoleh dari penelitian menunjukkan hubungan positif dan siginifikan secara statistik antara orientasi pelayanan dengan semangat tim $(r=+0,396$, sig $<0,05)$. Hubungan yang positif berarti bahwa semakin tinggi orientasi pelayanan, maka semakin besar semangat tim atau kebersamaan, persahabatan, dan kepedulian di antara anggota organisasi dalam bekerja. Hasil penelitian ini serupa dengan pendapat yang menyatakan adanya hubungan positif yang signifikan antara orientasi pelayanan dengan semangat tim.

Hubungan antara orientasi pelayanan dengan komitmen terhadap organisasi merupakan hubungan yang positif dan siginifikan secara statistik $(\mathrm{r}=+0,432$, sig $<0,05$ ). Hubungan yang positif berarti bahwa semakin tinggi orientasi pelayanan, maka semakin besar komitmen terhadap organisasi, Hal ini didukung oleh pernyataan bahwa organisasi yang berorientasi pelayanan akan memberikan manfaat psikologis berupa komitmen terhadap organisasi.

Semangat tim dengan komitmen terhadap organisasi memiliki hubungan yang positif dan signifikan secara statistik ( $\mathrm{r}=+0,538$, sig $<0,05)$. Hubungan positif ini diartikan sebagai semakin besar semangat tim atau rasa kebersamaan dan kepedulian di antara sesama anggota organisasi, maka semakin tinggi pula komitmen terhadap organisasi. Semangat tim dalam lingkungan kerja suatu organisasi menciptakan identifikasi individu terhadap organisasi dan keinginan untuk tetap bekerja di organisasi tersebut. Hal ini disebabkan ketika karyawan meyakini dan menerima nilai organisasi, organisasi menjadi lebih menyenangkan sebagai tempat bekerja dibandingkan tempat lain dan kecenderungan untuk meninggalkan organisasi akan menurun. Semangat tim di dalam lingkungan kerja menjadikan karyawan memiliki orientasi tim. Karyawan yang berorientasi tim biasanya memiliki masa kerja yang lama dalam organisasi tersebut karena merasa senang dengan suasana lingkungan kerja yang kekeluargaan.

Karyawan yang memiliki komitmen tinggi terhadap organisasi akan tetap berada dalam organisasi dan berusaha keras untuk mencapai tujuan organisasi. Komitmen karyawan yang tinggi terhadap organisasi akan meningkatkan produktivitas dan kinerja organisasi.

Pada penelitian ini kontribusi terbesar sub variabel dalam orientasi pelayanan terhadap semangat tim adalah komunikasi standar pelayanan $(\mathrm{F}$ hitung $=34,710)$. Sedangkan kontribusi terbesar sub variabel dalam orientasi pelayanan terhadap komitmen terhadap organisasi adalah pencegahan kegagalan pelayanan ( $\mathrm{F}$ hitung $=$ 92,269). Kontribusi terkecil diberikan oleh sub variabel terhadap semangat tim adalah sub variabel pemberdayaan karyawan ( $F$ hitung $=4,262$ ). Kontribusi terkecil sub variabel terhadap komitmen yaitu sub variabel servant leadership (F hitung = 9,699). Sedangkan sub variabel pelatihan pelayanan tidak memberikan kontribusi terhadap semangat tim serta sub variabel pemberdayaan karyawan dan sub variabel pelatihan pelayanan tidak memberikan kontribusi terhadap komitmen terhadap organisasi (sig > 0,05).

Komunikasi standar pelayanan sebagai kontribusi terbesar terhadap semangat tim dikarenakan mengkomunikasikan standar pelayanan bagi semua anggota organisasi menjadikan anggota organisasi dapat memahami standar pelayanan sehingga sistem pelayanan dapat berfungsi efektif. Dengan kata lain, komunikasi yang lancar dan terbuka mengenai standar pelayanan menjadikan 
pemahaman tentang bagaimana suatu pelayan seharusnya dilakukan sehingga pelayanan dapat berjalan dengan efektif dan memberikan kepuasan bagi pelanggan, Kepuasan pelanggan yang tinggi akan meningkatkan profit organisasi.

Sub variabel pencegahan kegagalan pelayanan sebagai kontribusi terbesar terhadap komitmen pada penelitisan ini mungkin dikarenakan sub variabel komunikasi standar pelayanan yang memberikan konribusi terbesar terhadap semangat tim pada penelitian ini. Dengan adanya sosialisasi standar pelayanan kepada semua karyawan dapat meminimalkan terjadinya kegagalan pelayanan dan meningkatkan kemampuan organisasi untuk pulih dari kegagalan tersebut.

Kondisi rumah sakit sebagai organisasi yang berorientasi pelayanan yaitu (1). memiliki visi pelayanan yang jelas dan tersosialisasikan dengan baik, (2) menerapkan kepemimpinan yang tepat, (3) karyawan memperlakukan pasien dengan baik dan memberikan kenyamanan, (4) memberikan imbalan (gaji dan insentif) yang sesuai, (5) memiliki fasilitas dengan teknologi yang memadai, (6) memiliki sistem pencegahan kegagalan dan pemulihan kegagalan pelayanan yang terkoordinasi dengan baik, (7) memberikan pelatihan kepada karyawan secara berkala, dan (8) komunikasi yang lancar antara pihak manajemen dan karyawan maupun antar karyawan,

Agar terciptanya lingkungan kerja yang baik diperlukan: (a). Kejelasan dalam merumuskan tujuan dan kebijakan organisasi yang ditunjang oleh informasi yang mengalir lancar dan didukung oleh karyawan. (b). Komitmen dalam pencapian tujuan melalui pelibatan karyawan. (3). Standar kinerja yg menantang, mendatangkan kebanggaan dan memperbaiki kinerja karyawan. (4). Tanggung jawab terhadap pekerjaannya dengan didukung oleh manajer. (5). Penghargaan atas hasil kerja yang baik. (6). Kerja sama kelompok, rasa memiliki, percaya dan adanya saling menghargai satu sama lain.

\section{KESIMPULAN}

Dari penelitian ini dapat disimpulkan bahwa orientasi pelayanan berhubungan positif signifikan dengan semangat tim, orientasi pelayanan berhubungan positif signifikan dengan komitmen organisasi, dan semangat tim berhubungan positif signifikan dengan komitmen terhadap organisasi. Pemberdayaan karyawan memberikan kontribusi terkecil terhadap semangat tim dan tidak memberikan kontribusi terhadap komitmen organisasi pada perawat di RSUD A.W.Sjahranie Samarinda. Komunikasi standar pelayanan memberikan kontribusi terbesar terhadap semangat tim pada perawat di RSUD A.W.Sjahranie Samarinda. Pencegahan kegagalan pelayanan memberikan kontribusi terbesar terhadap komitmen organisasi pada perawat di RSUD A.W.Sjahranie Samarinda. Pemberdayaan karyawan memberikan kontribusi terkecil terhadap semangat tim pada perawat di RSUD A.W.Sjahranie Samarinda. Servant leadership memberikan kontribusi terkecil terhadap komitmen organisasi pada perawat di RSUD A.W.Sjahranie Samarinda. Pelatihan karyawan tidak memberikan kontribusi terhadap semangat tim dan terhadap komitmen organisasi pada perawat di RSUD A.W.Sjahranie Samarinda. Untuk meminimalkan kesenjangan yang terjadi terutama antara pihak manajemen dan pelaksana komitmen, upaya yang dapat dilakukan adalah: memastikan mengkomunikasikan visi, misi, dan tujuan pelayanan secara konsisten kepada karyawan. Menanamkan kepercayaan dan keterbukaan melalui komunikasi dan cepat memberi feed back yang menimbulkan motivasi. Memastikan memberi kesempatan kepada karyawan untuk tumbuh dan berkembang melalui pemberdayaan karyawan, pelatihan, jenjang karir yang jelas, dan program pendidikan. Memastikan melakukan tindakan pencegahan kegagalan pelayanan dan pemulihan kegagalan pelayanan sesegera mungkin apabila terjadi kegagalan pelayanan atau mendapat komplain. Melakukan survei kepuasan kerja karyawan secara berkala sebagai bahan pertimbangan menetapkan kebijakan agar dapat meningkatkan kinerja dan mutu pelayanan. Melakukan survei kepuasan pelanggan secara berkala sebagai bahan pertimbangan meningkatkan mutu pelayanan 


\section{DAFTAR PUSTAKA}

[1]. Azwar, A., 1996, Pengantar Administrasi Kesehatan, Edisi Ketiga, Bina Rupa Aksara, Tangerang.

[2]. Robbins, S.P. dan Judge, T.A., 2008, Perilaku Organisasi (terj.), Buku 1, Edisi 12, Salemba Empat, Jakarta.

[3]. Lytle, R.S. dan Timmerman, J.E., 2006, Service Orientation and Performance: An Organizational Perspective, Journal of Services Marketing, Vol. 20, Issue 2, p.136-147.

[4]. Lytle, R.S., Hom, P.W., dan Mokwa, M.P., 1998, SERV*OR: A Managerial Measure of Organizational Service-Orientation, Journal of Retailing, Vol. 74(4), p.45589.

[5]. Gonzalez, J.V. dan Garazo, T.G., 2006, Structural Relationships Between Organizational Service Orientation, Contact Employee Job Satisfaction, and Citizenship Behaviour, International Journal of Service Industry Management, Vol. 17(1), p. 23-50.

[6]. Jaworski, B.J. dan Kohli, A.K., 1993, Market Orientation : Antecedents and Consequences, Journal of Marketing, Vol. 57, p.53-70.

[7]. Purba, D.E. dan Seniati, A.N.L., 2004, Pengaruh Kepribadian dan Komitmen Organisasi terhadap Organizational Citizenzhip Behavior, Makara Sosial Humaniora, Vol. 8 (3), p.105-111.

[8]. Boyt, T., Lusch, R., dan Mejza, M., 2005, Theoretical Models of the Antecedents and Consequences of Organizational, Workgroup, and Professional Esprit de Corps, European Management Journal, Vol. 23 (6), p.682-701.
[9]. Warsi, S., Fatima, N., dan Sahibzada, S.A., 2009, Study on Relationship Between Organizational Commitment and its Determinants among Private Sector Employees of Pakistan, International Review of Business Research Papers, Vol. 5 (3), p. 399- 410.

[10]. Porter, L. W., Steers, R. M., Mowday, R. T., dan Boulian, P. V. , 1974, Organizational Commitment, Job Satisfaction and Turnover Among Psychiatric Technicians. Journal of Applied Psychology, Vol. 59 (5), p. 603609.

[11]. Profil Rumah Sakit Umum Daerah Abdul Wahab Sjahranie Samarinda Tahun 2009.

[12]. Amriyati, Sumarni, dan Sutoto, 2003, Kinerja Perawat Ditinjau Dari Lingkungan Kerja dan Karakteristik Individu, Sains Kesehatan, Vol. 16(2), p. 331-345.

[13]. Teng, C.C. dan Barrows, C.W., 2009, Service Orientation: Antecedents, Outcomes, and Implications for Hospitality Research and Practice, The Service Industries Journal, Vol. 29 (10), p.1413-1435.

[14]. Hallowell, R., Schlesinger, L.A., dan Zornitsky,J., 1996, Internal Service Quality, Customer and Job Satisfaction: Linkages and Implications for Management, Human Resource Planning, Vol. 19 (2), p.20-30.

[15]. Swansburg, R., C., 1990, Management and Leadership for Nurses Managers. Second Edition, Jones \& Bartlett Publishers Inc., Boston. 